\title{
Birth weight and its impacts on testicular development in boars
}

\author{
F.R.C.L. Almeida', P.A. Auler', G.H.F. A. Moreira' ${ }^{1}$, R.B.C. Jardim', F.P. \\ Bortolozzo $^{2}$ and $\mathrm{H}$. Chiarini-Garcia ${ }^{1}$ \\ ${ }^{1}$ Department of Morphology, Federal University of Minas Gerais, Avenida Antônio Carlos, 6627, CEP \\ 31.270-901, Belo Horizonte, MG, Brazil; ${ }^{2}$ Department of Animal Medicine, Veterinary Faculty, Federal \\ University of Rio Grande do Sul, Porto Alegre, RS, Brazil
}

Selection for prolificacy appears to have created an imbalance between the number of conceptuses surviving to the post-implantation period and uterine capacity. Limited placental development due to intra-uterine crowding in early gestation results in entire litters with characteristics of IntraUterine Growth Restriction at birth, due to a great competition among fetuses for nutrients and oxygen, resulting in lighter fetuses at term (Foxcroft et al., 2009). The implications of birth weight on postnatal development, such as growth performance, muscle accretion and intestine morphology, have been described previously (Alvarenga et al., 2013). However, there is little information on its effects on testicular development in pigs. In the present study, we investigated some biometrical and morphological parameters of testicular development in light birth weight boars.

New-born male pigs ( $n=56$; PIC genotype), born to $4^{\text {th }}-6^{\text {th }}$ parity sows and in litters of 10 to 15 pigs, were identified as falling into two birth weight groups: high (HW: range 2.0 to $2.2 \mathrm{~kg}$ ) and low (LW: range 0.8 to $1.0 \mathrm{~kg}$ ) littermates. A sub-set of 28 males from each experimental group was castrated at 8 days post-partum for evaluation of testicular biometrical (testes weight and volume) and histomorphologic characteristics. The other sub-set of 28 animals was castrated at 8 months of age for evaluation of the same testicular parameters. Testes' samples from both experimental groups at the evaluated ages were fixed in a glutaraldehyde solution and embedded in glycol methacrylate plastic resin. Histological sections ( $3 \mu \mathrm{m}$ ) were cut from these resin blocks and stained with toluidine bluesodium borate for histomorphometric analysis (Chiarini-Garcia et al., 2011). These analysis included measurement of the seminiferous cords/tubules diameter, number of Sertoli cells present in twenty cross sections of cords/tubules, and the total Sertoli cell number per testis. Finally, to estimate sperm production capacity, the number of spermatids was calculated per gram of testis using a Neubauer chamber. Data were analyzed as a randomized complete block design, where litter of origin was blocked, and treatment effects on the parameters evaluated were analyzed using the general linear model (GLM) procedure of SAS (SAS Institute Inc., Cary, NC). Least square means were compared using the Student $T$ test with $P<0.05$ being considered significant. Important associations among characteristics measured were examined across treatment groups using correlation analysis (INSIGHT procedure of SAS).

At 8 days of age, LW males had lighter body and testicular weights, lower testicular volume, and also showed lower testis weight relative to body weight (GSI - Gonadossomatic Index) compared to their HW littermates (Table 1). A litter of origin effect was observed for testicular weight, GSI and testicular volume $(\mathrm{P}<0.05)$. At 8 months of age, LW males also showed lower body and testicular weights, and testicular volume than their HW counterparts (Table 2). On the other hand, the GSI was similar to their HW littermates. A litter of origin effect was also observed for GSI at 8 months of age $(P<0.05)$, which revealed the importance of the use of littermates when designing experiments of this kind to account for the differences due to family. Moreover, birth weight did not affect the diameter of seminiferous cords and the number of Sertoli cells per seminiferous cords cross section in 8 days old males. Similarly, diameter of the seminiferous tubules and the number of Sertoli cells 
per seminiferous tubules cross section at stage I of the seminiferous epithelium cycle in 8 months old males were not affected by birth weight. However, LW males showed lower total Sertoli cell number per testis in both ages evaluated. At 8 days old, testicular weight was highly correlated with body weight $(r=0.72 ; P=0.003)$ and Sertoli cell number per testis $(r=0.65 ; P=0.012)$; body weight was also positively correlated with Sertoli cell number per testis $(r=0.56 ; P=0.04)$. At 8 months old, the number of spermatids per testis was lower in LW boars, however, when calculated per gram of testis the result was similar between both experimental groups (Table 2).

Table 1. Biometrical and histomorphometrical data (LS means \pm SEM) from HW and LW boars at 8 days of age

\begin{tabular}{lccc}
\hline Parameter & \multicolumn{2}{c}{ Treatment } & $P$-value \\
& $H W(n=14)$ & $L W(n=14)$ & $<0.01$ \\
\hline Body weight, $\mathrm{kg}$ & $3.62 \pm 0.12^{\mathrm{a}}$ & $2.37 \pm 0.12^{\mathrm{b}}$ & $<0.01$ \\
Testicular weight, g & $2.42 \pm 0.14^{\mathrm{a}}$ & $1.36 \pm 0.14^{\mathrm{b}}$ & $<0.05$ \\
GSI & $0.67 \pm 0.03^{\mathrm{a}}$ & $0.56 \pm 0.03^{\mathrm{b}}$ & $<0.01$ \\
Testicular volume, $\mathrm{cm}^{3}$ & $3.94 \pm 0.22^{\mathrm{a}}$ & $2.28 \pm 0.22^{\mathrm{b}}$ & $\mathrm{NS}$ \\
Seminiferous cord (SC) diameter, $\mu \mathrm{m}$ & $48.0 \pm 1.16^{\mathrm{a}}$ & $50.6 \pm 1.16^{\mathrm{a}}$ & $<0.01$ \\
Sertoli cell number per testis, $\times 10^{9}$ & $1.24 \pm 0.13^{\mathrm{a}}$ & $0.60 \pm 0.13^{\mathrm{b}}$ & $\mathrm{NS}$ \\
Sertoli cell number per cross section SC & $19.57 \pm 0.53^{\mathrm{a}}$ & $18.41 \pm 0.53^{\mathrm{a}}$ & \\
\hline
\end{tabular}

a,b Different letters within a row differ $(P<0.05)$.

Table 2. Biometrical and histomorphometrical data (LS means \pm SEM) from HW and LW boars at 8 months of age

\begin{tabular}{lccc}
\hline Parameter & \multicolumn{2}{c}{ Treatment } & $P$-value \\
& $H W(n=14)$ & $L W(n=14)$ & \\
\hline Body weight, $\mathrm{kg}$ & $177.00 \pm 3.70^{\mathrm{a}}$ & $156.00 \pm 3.70^{\mathrm{b}}$ & $<0.01$ \\
Testicular weight, g & $415.20 \pm 15.30^{\mathrm{a}}$ & $357.90 \pm 15.30^{\mathrm{b}}$ & $<0.05$ \\
GSI & $2.36 \pm 0.09^{\mathrm{a}}$ & $2.30 \pm 0.09^{\mathrm{a}}$ & $\mathrm{NS}$ \\
Testicular volume, $\mathrm{cm}^{3}$ & $681.90 \pm 31.10^{\mathrm{a}}$ & $580.60 \pm 31.10^{\mathrm{b}}$ & $<0.05$ \\
Seminiferous tubule $(\mathrm{ST})$ diameter, $\mu \mathrm{m}$ & $248.30 \pm 4.70^{\mathrm{a}}$ & $241.60 \pm 4.70^{\mathrm{a}}$ & $\mathrm{NS}$ \\
Spermatid number per testis, $\times 10^{6}$ & $713.60 \pm 283.30^{\mathrm{a}}$ & $465.90 \pm 187.45^{\mathrm{b}}$ & $<0.05$ \\
Spermatid number per gram of testis, $\times 10^{6}$ & $1.70 \pm 0.64^{\mathrm{a}}$ & $1.29 \pm 0.43^{\mathrm{a}}$ & $\mathrm{NS}$ \\
\hline
\end{tabular}

a,b Different letters within a row differ $(P<0.05)$.

Together, these findings showed that biometrical and morphological testicular parameters are compromised in LW neonatal and adult boars, which is mainly due to their small body and testicular sizes. Therefore, we infer that birth weight may be used as an important criterion for boar selection for artificial insemination studs. Further investigations are necessary to study the impact of birth weight on reproductive parameters in adult boars, such as age at puberty and sexual maturation, libido, semen quality, and reproductive hormone profiles.

Funded by Capes, CNPq and Fapemig.

\section{References}

Alvarenga, A. L. N., Chiarini-Garcia, H., Cardeal, P. C., Moreira, L. P., Foxcroft, G. R., Fontes, D. O. and Almeida, F. R. C. L. 2013. Intra-uterine growth retardation affects birth weight and postnatal development in pigs, impairing muscle accretion, duodenal mucosa morphology and carcass traits. Reprod. Fertil. Dev. http:// www.publish.csiro.au/paper/RD12021.htm

Chiarini-Garcia, H., Parreira, G. G., and Almeida, F. R. C. L. 2011. Glycol methacrylate embedding for improved morphological, morphometrical and immunohistochemical investigations under light microscopy: testes as a model. In 'Light Microscopy: Methods and Protocols'. (Eds H. Chiarini-Garcia and R. C. N. Melo) pp 3-18. (Humana Press: Totowa, New Jersey).

Foxcroft, G. R., Dixon, W. T., Dyck, M. K., Novak, S., Harding, J. C. S. and Almeida, F. R. C. L. 2009. Prenatal programming of postnatal development in the pig. In 'Control of Pig Reproduction VIII'. (Eds H. RodriguezMartinez, J. L. Vallet, and A. J. Zicik) pp 213-231. (Nottingham University Press, Thrumpton, Nottingham). 